\title{
Disappearance of a Nassau grouper spawning aggregation off the southern Mexican Caribbean coast
}

\author{
Alfonso Aguilar-Perera ${ }^{1,2, *}$ \\ ${ }^{1}$ Department of Marine Sciences, University of Puerto Rico, Mayagüez, PR 00681-9013 \\ ${ }^{2}$ Present address: Departmento de Biología Marina, Universidad Autónoma de Yucatán, Km. 15.5, carretera \\ Mérida-Xmatkuil, A.P. 4-116 Itzimná, C.P. 97100, Mérida, Yucatán, México
}

\begin{abstract}
A Nassau grouper spawning aggregation formed in large numbers (e.g. 1000 to 15000 ind.) for more than $50 \mathrm{yr}$ at the traditional aggregation site off Mahahual, Quintana Roo, Mexico (eastern Yucatan Peninsula). However, in the early 1990s the aggregation ceased forming at the site, and only small aggregations were found south of the site (1 to $2 \mathrm{~km}$ ) moving northward along the fore reef. The spawning aggregation progressively disappeared, and in 1996 no aggregation formed even in areas adjacent to the site. Changes in grouper mean total length, size-frequency distribution and sex ratios analyzed from the commercial catch (taken from the migrating aggregation), showed that mean body size fluctuated and that the sex ratio was female-biased. The grouper aggregation showed evidence of overexploitation in terms of disappearance, reduction in number and fluctuations in size; however, the latter may be a recruitment effect. Fishery management and conservation alternatives, through the implementation of a network of no-take marine reserves and a total fishing ban, are necessary for protecting the Nassau grouper and other aggregating reef fishes, not only in the Mexican Caribbean Sea but also along the Mesoamerican Barrier Reef System.
\end{abstract}

KEY WORDS: Spawning aggregation · Grouper · Mexican Caribbean Sea $\cdot$ Coral reefs $\cdot$ Serranidae Resale or republication not permitted without written consent of the publisher

\section{INTRODUCTION}

Fish spawning aggregations are receiving increasing worldwide attention due to their biological and fishery importance (Claydon 2004), since many of these aggregations have drastically declined due to over-fishing (Domeier \& Colin 1997, Sadovy \& Domeier 2005). Such is the case of various grouper species (Serranidae) from the Indo-Pacific and western Atlantic Oceans (Luckhurst 2003, Claydon 2004), which migrate to form annual spawning aggregations at traditional aggregation sites during specific periods of the year (Domeier \& Colin 1997, Sadovy \& Eklund 1999).

In the western Atlantic Ocean, the Nassau grouper Epinephelus striatus is among the most commercially important, shallow-water, aggregating grouper species (Sadovy \& Eklund 1999). It concentrates annually on traditional aggregation sites in coral reefs during full moon days of December and January after migrating up to $200 \mathrm{~km}$ (Colin 1992, Bolden 2000). The aggregation sites are considered as traditional, since not only are they used for spawning by aggregating groupers with extremely high site fidelity and longevity for decades (Colin 1996), but also by aggregating lutjanids and scarids for spawning (Domeier \& Colin 1997, Luckhurst 2003).

During the last 30 yr, various Nassau grouper spawning aggregations have been documented in the wider Caribbean region, including: Bermuda (Luckhurst 2003), the Bahamas (Smith 1972), the US Virgin Islands (Olsen \& La Place 1979), Puerto Rico (Colin 1982), the Cayman Islands (Whaylen et al. 2004), Belize (Carter et al. 1994, Sala et al. 2001), Cuba (Claro \& Lindeman 2003) and Mexico (Aguilar-Perera 1994, AguilarPerera \& Aguilar-Dávila 1996). However, of the documented aggregations (>60), a quarter no longer form due to over fishing (Sadovy \& Eklund 1999). Therefore, because of the alarming declines and aggregation dis- 
appearance cases, the Nassau grouper is considered as 'endangered' by the IUCN Red List (Cornish \& Eklund 2003) and 'threatened' by the American Fisheries Society (Musick et al. 2000).

While declines of many Nassau grouper aggregations in the wider Caribbean region are recognized (Sadovy \& Eklund 1999, Luckhurst 2003, Sadovy \& Domeier 2005), relatively little is known about the biological and fishery characteristics of these aggregations in the Mexican Caribbean Sea. Of the Nassau grouper aggregations historically known to fishermen off southern Quintanna Roo's coast (eastern Yucatan Peninsula), one of the most heavily exploited is located off Mahahual (Aguilar-Perera 1994, Aguilar-Perera \& Aguilar-Dávila 1996, Sosa-Cordero \& Cárdenas-Vidal 1996). Historically, fishermen in Mahahual used 3 types of fishing gears (i.e. hook-and-line, speargun and gillnets) for exploiting the aggregation (AguilarPerera 1994). During the early 1950 s to 1970 s hookand-line was used, while spear guns were used in the late 1960s through the early 1990s, and gillnets were used from 1989. Few studies provide a long-term record 1991 to 1997) for the Nassau grouper aggregation off Mahahual.

This study complements previous work (Aguilar-Perera 1994, Aguilar-Perera \& Aguilar-Dávila 1996) and aims to examine the status of the Nassau grouper spawning aggregation at the traditional site off $\mathrm{Ma}$ haual, Quintana Roo, in terms of the temporal dynamics in aggregation dimension (i.e. numerical composition of the aggregation and location of occurrence) and biological characteristics of individuals (e.g. size, sex ratio) over the course of 5 reproductive seasons (1991 to 1997).

\section{MATERIALS AND METHODS}

Study site. This study was conducted off Mahahual $\left(18^{\circ} 43^{\prime} \mathrm{N}, 87^{\circ} 42^{\prime} \mathrm{W}\right)$, formerly a fishing village but now a tourist resort located on the southern coast of Quintana Roo, Mexico (Fig. 1). Coral reefs of this region comprise part of the Mesoamerican Barrier Reef System (MBRS), a conservation region that includes Mexico, Belize, Guatemala and Honduras. The traditional aggregation site is located over coral reefs offshore of Mahahual village, $350 \mathrm{~m}$ from shore and $200 \mathrm{~m}$ from the shelf edge, with depths ranging from 6 to $20 \mathrm{~m}$ (AguilarPerera 1994, Aguilar-Perera \& Aguilar-
Dávila 1996) over a bottom comprised of low relief, patchy hard corals (Montastrea annularis and Agaricia spp.) interspersed with gorgonians (e.g. plexaurids and gorgonids).

Underwater visual censuses. Underwater visual censuses (UVCs) were performed for recording spawning displacement, coloration changes, mating behavior, and the dimension (i.e. number of individuals) of aggregating Nassau groupers during the reproductive seasons of December and January from 1991-1997 (except January 1994, 1995 and December 1996, due to logistical problems, such as bad weather). Underwater visibility varied between 30 and $50 \mathrm{~m}$. SCUBA incursions were conducted daily by 2 divers during mornings (07:00 to 09:00 h) and evenings (16:00 to $18: 00 \mathrm{~h}$ ). Time for finding and observing groupers consisted of $5 \mathrm{~h} \mathrm{~d}^{-1}$ during 3 to $6 \mathrm{~d}$ periods every season. We attempted to time our arrival at the aggregation site to cover a period encompassing a couple of

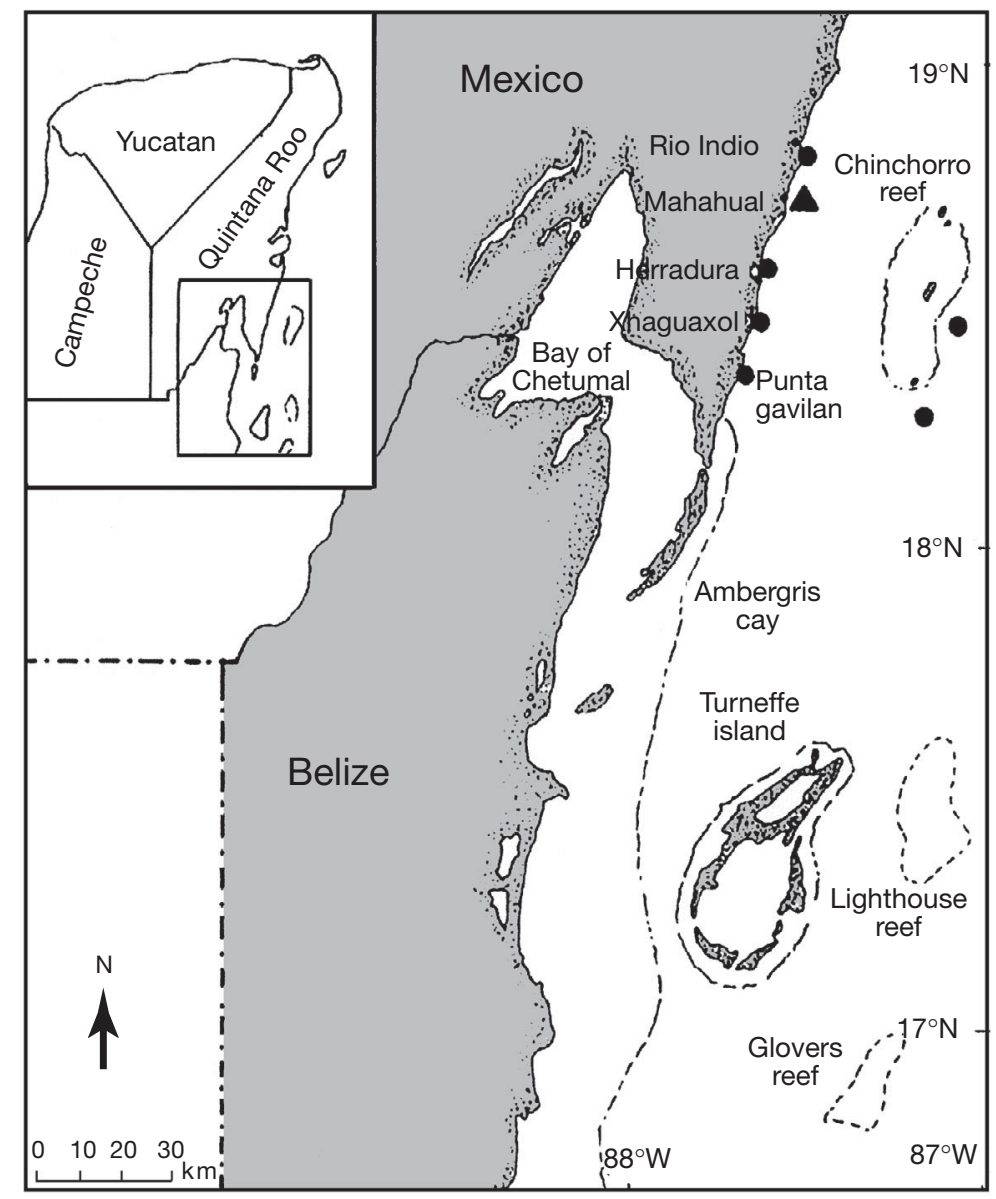

Fig. 1. Epinephelus striatus. Southern coast of Quintana Roo, eastern Yucatan Peninsula, Mexico, showing some aggregation sites (•), including that off Mahahual (\) (modified from Aguilar-Perera \& Aguilar Dávila 1996) 
days on either side of the full moon. At the traditional aggregation site, UVCs were performed early in the mornings and late afternoons at depths averaging $12 \mathrm{~m}$. Additional UVCs averaging $10 \mathrm{~m}$ and using either SCUBA or snorkeling were required when searching for migrating groupers in adjacent areas along the deep fore reef edge. This effort extended as far south as 1 to $2 \mathrm{~km}$ from the traditional site off Mahahual. Searching was concentrated in areas south of the traditional aggregation site, since according to Aguilar-Perera \& Aguilar-Dávila (1996) the grouper aggregation moves northwards. The dimension of the aggregation was estimated using both topographic reference points and the approximate size of individuals comprising the aggregation. Sometimes, such estimation was difficult since the aggregation was constantly moving and fishermen were always chasing it. The general procedure adopted during UVCs relied on 2 approaches: (1) following the reef edge (i.e. over the spoor and groove system) at the reef promontory where the traditional aggregation site is located, and (2) following the reef edge (at 14 to $18 \mathrm{~m}$ depth) from the traditional aggregation site to southern areas for finding migrating aggregations. Divers completed $>50 \mathrm{~h}$ of underwater surveys both on the aggregation site and adjacent areas.

Fishery sampling. Nassau groupers were sampled directly from the commercial gillnet catch comprising the same reproductive seasons when UVCs were performed. Gillnets (15 cm stretched mesh) were regularly set by fishermen during afternoons (15:00 h) and hauled early in the next morning (05:00 h). Occasionally, fishermen removed groupers during morning hauling and reset nets back in the water for hauling again in the afternoon. Fishermen were targeting migrating groupers at the fore reef, perpendicular to the reef crest, at various locations 1 to $2 \mathrm{~km}$ south to the traditional aggregation site off Mahaual (AguilarPerera \& Aguilar-Dávila 1996). Due to the ephemeral residence of groupers off Mahaual (i.e. up to $8 \mathrm{~d}$ per full moon) and the fishery-dependent sampling, data obtained varied according to time available for fishermen to fish. For instance, in December 1991 and January 1992, at least 6 boats, each using 2 gillnets $(150 \mathrm{~m}$ long $\times 5 \mathrm{~m}$ wide) were fishing, while eventually (i.e. December 1995 and January 1996) only 3 boats using 1 gillnet each (200 m long $\times 5 \mathrm{~m}$ wide) were active. These variations were evident by the end of the study (1997), when sampling the commercial catch was problematic due to a fishing ban imposed by fishery authorities; thus, groupers were not available. Landing reports (i.e. catch per boat or total catch per reproductive season) were not available for analyses due to logistical problems derived from timing and distance to other landing locations.
To the extent possible at the landing site off Mahahual groupers were: (1) measured for total length to the nearest centimeter, (TL), (2) weighed to whole weight ( $g$ ) and (3) sexed. Sexing involved examining removed gonads either macroscopically by distinguishing gonad coloration, consistency and presence of oocytes (no transitional phases were witnessed), or microscopically in the laboratory following embedding in paraffin, sectioning at 4 to $5 \mu \mathrm{m}$, and staining in haematoxylin and eosin. Speared groupers were not available for analysis because catches were landed far from the Mahahual site. In late 1993, spear-fishing was banned by fishery authorities, and in 1997 the fishing of any aggregating grouper during reproductive seasons (i.e. December to February) at the traditional aggregation site or adjacent areas was banned.

Statistics. Prior to analyses, collected data on grouper lengths and sex determination were tested for normality and homogeneity of variance to validate using parametric statistics. The Kolmogorov-Smirnov 2-sample test (D), $t$-test (t), $\chi^{2}$ and ANOVA (Sokal \& Rohlf 1995) were used to compare fish size-frequency distributions, mean size (total length, TL), sex ratio and mean size variations among reproductive periods, respectively.

\section{RESULTS}

In December 1991, a relatively small, migrating aggregation ( 50 to 60 groupers) was found moving along the fore reef border $1 \mathrm{~km}$ south of the traditional aggregation site $2 \mathrm{~d}$ after the full moon (Table 1 ). In January 1992, a larger group (<500 groupers) and 2 other smaller groups ( 200 each) were sighted further south $(\sim 2 \mathrm{~km})$ from the site the same day of the full moon, and in December 1992 another aggregation of 500 groupers was sighted $1 \mathrm{~d}$ after the full moon. In January 1993, a relatively larger aggregation ( 600 to 800 groupers) was located 2 d before full moon, while in December 1993 only 15 groupers were found on the day of the full moon. In all cases, groupers were migrating northward along the deep fore reef edge (15 m depth). During the 1996 and 1997 seasons, no migrating grouper aggregation was found in any adjacent area, even south or north from the traditional aggregation site. Nassau grouper spawning events (i.e. gamete release) were not witnessed, just the aggregation in itself with many individuals showing distended abdomens and others displaying coloration changes (e.g. bicolor phase) as indicative that groupers were in spawning period.

A total of 778 Nassau groupers, taken from the commercial catch, were examined. Females $(\mathrm{N}=440$, $56.5 \%)$ significantly outnumbered males $(\mathrm{N}=338$, 
Table 1. Epinephelus striatus. Mean lengths per sex and reproductive season, and sex ratios taken from the commercial catch. Additionally, numerical dimensions of aggregations sighted by UVCs in relation to full moon days. N: number of fish, L: mean length (total length in $\mathrm{cm}$ ), SD: standard deviation, DAS: day when aggregation was sighted, No. of groupers: fish sighted by underwater visual censuses, DASAFM: days around full moon when aggregation sighted, afmd: after full moon day, bfmd: before full moon day, fmd: full moon day, Sampling: corresponds to the length of fieldwork in days

\begin{tabular}{|c|c|c|c|c|c|c|c|c|c|c|c|c|c|c|c|c|c|}
\hline \multirow{2}{*}{$\begin{array}{l}\text { Reproductive } \\
\text { season }\end{array}$} & \multicolumn{3}{|c|}{ Females } & \multicolumn{3}{|c|}{ Males } & \multirow{2}{*}{$\begin{array}{c}\text { Sex ratio } \\
\text { F:M }\end{array}$} & \multicolumn{2}{|c|}{ Sampling } & \multirow{2}{*}{\multicolumn{2}{|c|}{$\begin{array}{l}\text { Full moon } \\
\text { Dec Jan }\end{array}$}} & \multirow{2}{*}{\multicolumn{2}{|c|}{$\begin{array}{c}\text { DAS } \\
\text { Dec Jan }\end{array}$}} & \multicolumn{2}{|c|}{ No. of groupers } & \multicolumn{2}{|c|}{ DASAFM } \\
\hline & $\mathrm{N}$ & L & SD & $\mathrm{N}$ & $\mathrm{L}$ & $\mathrm{SD}$ & & Dec & Jan & & & & & Dec & Jan & Dec & Jan \\
\hline Dec 91-Jan 92 & 147 & 59.2 & 5.3 & 77 & 58.2 & 5.9 & $1.9: 1$ & $23-26$ & $19-25$ & 21 & 19 & 23 & 19 & $50-60$ & $\sim 700$ & 2 afmd & fmd \\
\hline Dec 92-Jan 93 & 167 & 59.3 & 5.6 & 126 & 58.6 & 5.0 & $1.3: 1$ & $10-15$ & $6-12$ & 9 & 8 & 10 & 6 & $\sim 500$ & $600-800$ & 1 afmd & $2 \mathrm{bfmd}$ \\
\hline December 93 & 60 & 55.4 & 4.1 & 57 & 54.7 & 4.2 & $1: 1$ & $28-31$ & nd & 28 & nd & 28 & nd & $\sim 15$ & nd & fmd & nd \\
\hline December 94 & 39 & 57.5 & 3.7 & 31 & 58.1 & 3.2 & $1.2: 1$ & $18-21$ & nd & 18 & nd & 18 & nd & None & nd & nd & nd \\
\hline Dec 95-Jan 96 & 20 & 60.8 & 6.8 & 41 & 58.5 & 5.3 & $0.48: 1$ & $6-9$ & $5-8$ & 7 & 5 & 6 & 5 & None & nd & nd & nd \\
\hline January 97 & 7 & 60.0 & 6.2 & 6 & 58.3 & 2.7 & $1.1: 1$ & nd & 21 & 23 & nd & 21 & nd & None & nd & nd & nd \\
\hline Total & 440 & 58.7 & & 338 & 57.8 & & & & & & & & & & & & \\
\hline
\end{tabular}

$43.4 \%)$ in overall catches $\left(1.3: 1, \chi^{2}=13.3, \mathrm{p}<0.001\right)$, while monthly sex ratios varied (Table 1$)$. Of the total sample, at least 412 groupers $(52.9 \%)$ were weighted, of which 178 were males (1.3 to $10.2 \mathrm{~kg}$ ) and 233 were females (1.8 to $9.6 \mathrm{~kg}$ ). Dates of grouper arrival to reefs (based on fishermen catches) varied from 2 to $3 \mathrm{~d}$ either before or after the day of the full moon (Table 1). Sex ratio estimation depended upon the availability of groupers from the catch. For many reproductive seasons, the sex ratio was close to 1:1, except for a female bias in December 1991 to January 1992 ( $\mathrm{N}=224, \chi^{2}$, $\mathrm{p}<0.001$ ) and a male bias in December 1995 to January $1996\left(\mathrm{~N}=61, \chi^{2}, \mathrm{p}<0.01\right)$. Sex ratios for each reproductive season are shown in Table 1.

Size-frequency distributions showed relative changes in the population over time (Fig. 2). Grouper size ranged from 39 to $88 \mathrm{~cm}$ TL $($ mean $=58.3)$, with males ranging from 39 to $86 \mathrm{~cm}$ TL $($ mean $=57.8 \mathrm{~cm}$ ) and females ranging from 46 to $88 \mathrm{~cm}$ TL (mean = $58.7 \mathrm{~cm}$ ). Mean length varied significantly within sexes across reproductive seasons (ANOVA, $F=6.64$ for females, $\mathrm{p}<0.0001$; $F=5.26$ for males, $\mathrm{p}<0.0001$ ). Mean lengths between females and males were never significantly different within any single reproductive season (Table 1). For 3 reproductive seasons, samples were available for both the December and January aggregations. Size-frequency distributions for December and January were significantly different in 1991 to $1992(D=0.350, \mathrm{p}<0.01)$ and 1992-1993 $(D=0.226$, $\mathrm{p}<0.01)$. In contrast, for December 1995 and January 1996, size-frequency distributions were not significantly different.

Successive size-frequency distributions from the catch reflected changes in the population size structure over time. It is notable that a large, potential recruitment event may have occurred in December 1992 and December 1993 with an absence of larger (>72 cm TL) individuals observed in previous seasons; such large recruitment was not evident in any other

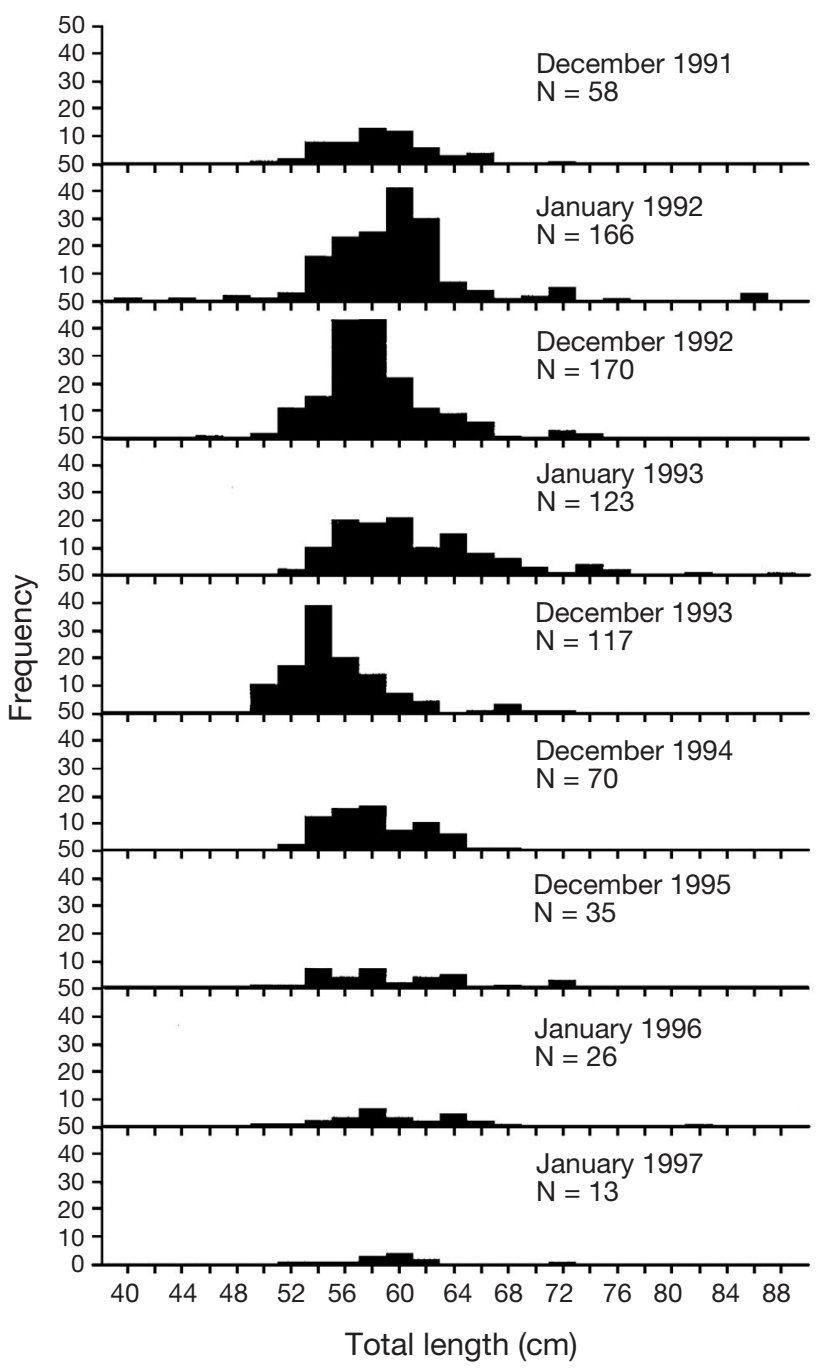

Fig. 2. Epinephelus striatus. Size-frequency distributions of Nassau grouper (male and female) taken by fishermen using gillnets from the adjacent areas to the traditional aggregation site off Mahahual, Quintana Roo, Mexico (modified from Aguilar-Perera 2000) 
season (Fig. 2). The December 1993 recruitment was evidenced by a significant decrease in mean size, for both males and females, while subsequent growth resulted in a significant increase in average females size between December 1993 and 1994 (Tukey test, p < 0.05). Drastic declines in observed abundance mirrored declines in fish sampled over the same period (e.g. 58 ind. in December 1991 to 13 ind. in January 1997; Fig. 1). The recruitment in December 1992 was apparently as good as that of December 1993.

\section{DISCUSSION}

The disappearance of the Nassau grouper spawning aggregation from the traditional site off Mahaual, and its eventual extirpation from adjacent areas, is unequivocal evidence of serious problems in this portion of the grouper population off the southern coast of Quintana Roo, Mexico. Reduction in numbers and the disappearance of individuals from the traditional aggregation site are suggestive that: (1) the aggregation declined due to over-fishing, and (2) fishing changed the grouper behavior resulting in spawning aggregation forming elsewhere.

A declining Nassau grouper aggregation off Belize (Carter et al. 1994), which is geographically close and potentially connected to Mahahual, showed an $80 \%$ reduction in abundance (from 15000 to 3000 ind.) in the last 25 yr. (Sala et al. 2001). In Mahahual, the progressive aggregation decline was similarly dramatic. After exploitation for more than $50 \mathrm{yr}$, the aggregation off Mahahual still formed (i.e. at least 1000 to 15000 ind.) at the traditional aggregation site (Aguilar-Perera 1994). By the early 1990s, the aggregation no longer formed at this site, but migrating aggregations were observed further south (up to $2 \mathrm{~km}$ ) from the site moving northward (Aguilar-Perera \& Aguilar-Dávila 1996). Even more dramatic was the fact that after 1996 no migrating aggregations were sighted in adjacent areas. The absence of any aggregation during 1996 to 1997 provides evidence of the declining condition, likely due to overexploitation during the previous $50 \mathrm{yr}$.

While the conclusions as to why the Nassau grouper spawning aggregation stopped forming at the traditional site and disappeared are subjective, over-fishing is the most obvious and parsimonious explanation. Many reef fish spawning aggregations have strong site fidelity (Domeier \& Colin 1997, Claydon 2004), showing variable longevity of site use (Colin 1996) and plausibly representing a learned reproductive strategy (Helfman \& Schultz 1984). Heavy selective fishing pressure on grouper aggregations removes mature, older individuals (Coleman et al. 1996). Since many fish aggregation sites have been exploited consistently over long time periods (Luckhurst, 2003, Sadovy \& Domeier 2005), removing older fishes may leave no experienced individuals to lead new recruits to traditional aggregation sites, consequently promoting the aggregation's disappearance from traditional sites (Gilmore \& Jones 1992). Removing older Nassau groupers may prevent younger groupers from effectively finding the traditional site off Mahahual, although this has not been proven.

The historical perspective of a fishery is relevant when analyzing current status, since deleterious effects of over-fishing may have deep roots starting decades ago (Jackson et al. 2001). The Nassau grouper aggregation off Mahahual sustained a long-term fishery exploitation (Aguilar-Perera 1994); consequently, the current reduced aggregation may represent the remains of a former, much larger, population at this site. The grouper aggregation may have experienced the continuum of multiple responses attributable to historical over-fishing (e.g. size fluctuations, sex ratio alterations, sporadic recruitment, decreasing abundance). Unfortunately, no previous historical points of reference are available (i.e. detailed and sequential fishery data records) that could be scientifically compared with the current situation. Nonetheless, fishermen's accounts (as early as the 1950s) indicate extractions of up to $24 \mathrm{t}$ of groupers per reproductive season directly from the spawning aggregation off Mahahual. This catch represents only 4 to 5 days of fishing during December and January each using only hook-and-line gear. This historical pattern contrasts markedly with more recent conditions, where by the early 1990s only $3 \mathrm{t}$ were removed during December (AguilarPerera 1994), and by the mid-1990s less than $1 \mathrm{t}$ during January.

Based on the analyses of catches of migrating Nassau groupers, calculated mean sizes for both sexes slightly decreased in 1995 compared to those of 1991, coupled with an evident loss of larger individuals. However, an apparent stabilization in mean size was evident from 1993 to 1995. In general, a declining grouper mean size, especially the loss of large individuals, is an expected response of the population to intense fishing pressure (Coleman et al. 1996). Nevertheless, it is also possible that recruitment during December 1993 may have been manifested in 2 ways: (1) The mean grouper size was dramatically reduced, as many small individuals joined the aggregation, or (2) mean size increased as this cohort grew over time. Nonetheless, the recruitment was apparently a onetime occurrence over the study period, and such sporadic recruitment could be an indication of severe overexploitation.

Appeldoorn et al. (1992) showed that an apparent mean size increases in red hind Epinephelus guttatus in 
the US Virgin Islands occurred during a steady decline in catch per effort resulting from sustained low recruitment. The depleted state of the red hind population was subsequently confirmed by dramatic increases in abundance and mean size, following the closure of the aggregation site to fishing (Nemeth 2005). In light of this evidence, the patterns in Nassau grouper recruitment and mean size at Mahahual are consistent with expected responses to overexploitation.

Intense fishing pressure may significantly alter sex ratios in protogynous groupers, such as the red hind (Beets \& Friedlander 1992), leading to the possibility of sperm limitation and an accelerated decline in successful spawning. However, in gonochoristic species, such as the Nassau grouper (Sadovy \& Colin 1995), sex ratios are expected to approximate 1:1 under nonexploitation. In Mahahual, the sex ratio of groupers captured with gillnets was close to 1:1 for each reproductive season, with 2 exceptions (December 1991 to January 1992; December 1995 to January 1996). Sadovy \& Eklund (1999) warned that assessing sex ratios at fish aggregations is problematic because of fishing gear selectivity, differences in time spent by sexes at aggregation sites, differences in migration patterns and difficulties in correctly sexing individual fish. According to Bardach (1958), males may precede females to spawning sites, which may explain the sudden appearance of male-biased sex ratios observed in Mahahual in this study during December 1995 to January 1996, and in previous studies in 1990 to 1991 (Sosa-Cordero \& Cárdenas-Vidal 1996).

Although, off Mahahual, the Nassau grouper mean size and sex ratio remained relatively stable under pressure from heavy exploitation of the aggregation for more than $50 \mathrm{yr}$, it eventually disappeared from the traditional aggregation site. Using mean size and sex ratio for determining plausible fishing effects on highly exploited grouper populations is not viable since those parameters may not reflect immediate effects that may be confounded with recruitment effects. The grouper mean size for both sexes remained relatively constant during the reproductive seasons examined.

The traditional aggregation site off Mahahual was largely considered by fishermen to be among the most important for exploitation due to high landings (e.g. up to $24 \mathrm{t}$ ) and its close proximity to shore (Aguilar-Perera 1994). Additionally, it now represents the first scientifically documented aggregation site in Mexico for the Nassau grouper (Aguilar-Perera 1994, Aguilar-Perera \& Aguilar-Davila 1996, Sosa-Cordero \& CárdenasVidal 1996). An emerging pattern derived from analyses of fishery historical accounts is that fishing the aggregation appeared to be relatively 'sustainable' when hook-and-line was the principal gear used. The introduction of gillnets in combination with spear guns at aggregation site coincided with the depletion of the grouper population. The most compelling evidence of such depletion comes not necessarily from the length frequency distribution and mean size changes, but from the reduction in overall number of groupers over time.

That the aggregation disappeared from its traditional site off Mahahual may not necessarily mean the Nassau grouper is unable to form aggregations at other locations. Actually, this grouper commonly aggregates at various other sites along the southern coast of the Mexican Caribbean Sea (Aguilar-Perera 1994). Prior to 1990, anecdotal evidence by fishermen suggested the existence of at least 7 sites (Fig. 1). Based on a traditional environmental knowledge (TEK) from interviews with fishermen, at least 28 aggregation sites were recently reported for the Mexican Caribbean coast (around $250 \mathrm{~km}$ of coral reefs) (Sosa-Cordero et al. 2002). This is 4 times higher than previous accounts of just 7 sites. TEK allowed the identification of traditional aggregation sites not only for the Nassau grouper but also for other commercially important fish species (e.g. lutjanids, scarids), including other groupers (e.g. Mycteroperca venenosa).

The most recent studies of the Nassau grouper from the southern coast of Quintana Roo include records of an aggregation off Punta Gavilan $(\sim 50 \mathrm{~km}$ south of Mahahual), close to northern Belize in 'el blanquizal' (Medina-Quej et al. 2004). Based on TEK, fishermen contended that the aggregation comprised up to 3000 groupers during January 2004 (Medina-Quej et al. 2004). However, more detailed studies based on in situ observations are necessary to determine and confirm the status of this aggregation, along with the implications of potential displacement of individuals to other aggregation sites along the Mexican and Belizean coasts.

Both fishery-independent (e.g. video, photography, ultrasonic telemetry) and fishery-dependent (i.e. growth, sex ratio, size fluctuations, coloration changes during spawning) studies of known aggregation sites are required for monitoring: (1) aggregation magnitude (e.g. numbers and displacements), (2) elucidating migrating capabilities, and (3) evaluating the formation of undiscovered aggregations. Likewise, it is relevant to determine the relative importance of traditional grouper aggregation sites as spawning sites for other species, such as snappers (Lutjanidae) and parrotfishes (Scaridae). In the western Atlantic Ocean, many Nassau grouper traditional aggregations sites are used by other fish species with aggregations occurring at different times or simultaneously during brief periods, as occurs in Cuba (Claro \& Lindeman 2003), Belize (Sala et al. 2001), and Cayman Islands (Whaylen et al. 2004). The aggregation site off Mahahual has been used by species such as yellowfin grouper Myctero- 
perca venenosa and yellowtail parrotfish Sparisoma rubiprinne.

In the long term, removing groupers from aggregations may cause population depletion and disruption of the reproductive behavior (Coleman et al. 1996, Sala et al. 2001). Consequently, a complete protection from fishing is a recommended alternative for conservation and management (Nemeth 2005). For depleted grouper populations, protection exclusively during aggregations may not be sufficient (Sadovy \& Eklund 1999). Therefore, a conservation alternative using 'notake' (or fully protected) marine reserves (Roberts et al. 2001) would mitigate the fishing pressure on highly exploited groupers (Nemeth 2005). Globally, few fish aggregations are currently managed or specifically incorporated into marine reserve protection, and only 4 out of 55 no-take marine reserves in the western Atlantic Ocean consider fish spawning aggregations in their design (Sadovy \& Domeier 2005).

Along the MBRS, various Nassau grouper aggregation sites are known (Sadovy \& Eklund 1999), and in other areas studies have determined that some groupers may travel considerable distances (up to $220 \mathrm{~km}$ ) to reach aggregation sites (Colin 1992, Bolden 2000). Sala et al. (2001) found that only $5 \%$ of the Nassau groupers that spawn at Glover's reef in Belize appear to leave the atoll, which implies high site fidelity. A tag-recapture program initiated off the Mexican Caribbean Sea would help to determine the proportion of adult groupers displacing between aggregation sites for better elucidating the potential ecological connectivity along the MBRS. A network of no-take marine reserves along the MBRS, connecting potential 'pathways' followed by migrating groupers, and a complete fishing ban would be viable alternatives for conserving and managing the grouper stock in this region.

In Belize, management actions taken in 2002 by the government halted fishing and protected at least 13 fish-spawning aggregation sites, including those of Nassau grouper (Belize Government 2003). In the Mexican Caribbean Sea, there were no traditional fishery regulations (e.g. size, quotas, and fishing gear restrictions) from fishery authorities for exploiting the Nassau grouper aggregation. However, a complete ban was established as a result of the first scientific documentation of Mahahual (Aguilar-Perera 1994), and the Nassau grouper aggregation has been protected by fishery law since 1997. This law prohibits the removal of, not only the Nassau grouper but, also other grouper species (including Mycteroperca venenosa) during the reproductive season. The lack of population monitoring from 1997 to present (2006) prevents determination of the rate of recovery of the Nassau grouper aggregation, specifically off Mahahual.
Acknowledgements. In Mexico, many people provided assistance in numerous ways during earlier phases of this work, especially J. J. Schmitter-Soto, W. Aguilar-Dávila, E. SosaCordero, T. Camarena-Luhrs, A. Medina-Quej, D. CeballosCarrillo, M. Collí (Chandés), A. Sosa and C. Ramón. This work was partially funded by the former Centro de Investigaciones de Quintana Roo (now El Colegio de la Frontera Sur) and the Consejo Nacional de Ciencia y Tecnología. In Puerto Rico, R. S. Appeldoorn provided helpful suggestions in earlier phases of the manuscript and generously elaborated Fig. 2. Three anonymous reviewers provided useful criticisms for improving the manuscript.

\section{LITERATURE CITED}

Aguilar-Perera A (1994) Preliminary observations on the spawning aggregation of Nassau grouper, Epinephelus striatus, at Mahahual, Quintana Roo, Mexico. Proc Gulf Carib Fish Inst 43:112-122

Aguilar-Perera A, Aguilar-Dávila W (1996) A spawning aggregation of Nassau grouper Epinephelus striatus Pisces: Serranidae in the Mexican Caribbean. Environ Biol Fish 45:351-361

Appeldoorn R, Beets J, Bohnsack J, Bolden S and 5 others (1992) Shallow water reef fish stock assessment for the U.S. Caribbean. NOAA Tech Memo NMFS/SEFSC/304

Bardach JE (1958) On the movements of certain Bermuda reef fishes. Ecology 39:139-146

Beets J, Friedlander A (1992) Stock analysis and management strategies for red hind Epinephelus guttatus in the U.S. Virgin Islands. Proc Gulf Carib Fish Inst 42:66-79

Bolden SK (2000) Long-distance movement of a Nassau grouper Epinephelus striatus to a spawning aggregation in the central Bahamas. Fish Bull 98:642-645

Carter J, Marrow GJ, Pryor V (1994) Aspects of the ecology and reproduction of Nassau grouper, Epinephelus striatus, off the coast of Belize, Central America. Proc Gulf Carib Fish Inst 43:65-111

Claro R, Lindeman KC (2003) Spawning aggregation sites for snappers and groupers species (Lutjanidae and Serranidae) on the insular shelf of Cuba. Gulf Carib Res 14:91-106

Claydon J (2004) Spawning aggregations of coral reef fishes: characteristics, hypotheses, threats and management. Oceanog Mar Biol Annu Rev 42:265-302

Coleman FC, Koenig CC, Collins LA (1996) Reproductive styles of shallow-water groupers (Pisces: Serranidae) in the eastern Gulf of Mexico and the consequences of fishing spawning aggregations. Environ Biol Fish 47:129-141

Colin PL (1982) Aspects of the spawning of western Atlantic reef fishes. NOAA Tech Memo NMFS-SEFC 80:69-80

Colin PL (1992) Reproduction of the Nassau grouper, Epinephelus striatus (Pisces: Serranidae) and its relationship to environmental conditions. Environ Biol Fish 34:357-377

Colin PL (1996) Longevity of some coral reef fish spawning aggregations. Copeia 1996:189-191

Cornish A, Eklund EM (2003) Epinephelus striatus. In: IUCN 2003: IUCN Red List of Threatened Species. Available at: www.iucnredlist.org

Domeier ML, Colin PL (1997) Tropical reef fish spawning aggregations: defined and reviewed. Bull Mar Sci 60:698-726

Gilmore RG, Jones RS (1992) Color variation and associated behavior in the Epinephelinae groupers, Mycteroperca microlepis (Goode and Bam) and $M$. phenax Jordan \& Swain. Bull Mar Sci 51:84-103

Government of Belize (2003) Statutory Instrument No. 161. Avail- 
able at: http://nature.org/pressroom/press/press853.html

Helfman GS, Schultz ET (1984) Social transmission of behavioral traditions in a coral reef fish. Animal Behavior 32:379-384

Jackson JBC, Kirby MX, Berger WH, Bjorndal KA and 15 others (2001) Historical overfishing and the recent collapse of coastal ecosystems. Science 293:629-638

Luckhurst BE (2003) Development of a Caribbean regional conservation strategy for reef fish spawning aggregations. Proc Gulf Carib Fish Inst 54:668-679

Medina-Quej A, Herrera-Pavón AR, Poot-López G, SosaCordero E, Bolio-Moguel K, Haddad W (2004) Estudio preliminar de la agregación del mero Epinephelus striatus en 'El Blanquizal' en la costa sur de Quintana Roo, México. Proc Gulf Carib Fish Inst 55:557-569

Musick JA, Harbin MM, Berkeley SA, Burguess GH and 18 Others (2000) Marine, estuarine and diadromous fish stocks at risk of extinction in North America. Fisheries 25: $6-30$

Nemeth R (2005) Population characteristics of a recovering US Virgin Islands red hind spawning aggregation following protection. Mar Ecol Prog Ser 286:81-97

Olsen DA, La Place JA (1979) A study of a Virgin Islands grouper fishery based on a breeding aggregation. Proc Gulf Carib Fish Inst 31:130-144

Roberts CM, Bohnsack JA, Gell F, Hawkins JP, Goodridge R (2001) Effects of marine reserves on adjacent fisheries. Science 294:1920-1923

Sadovy Y, Colin PL (1995) Sexual development and sexuality

Editorial responsibility: Charles Birkeland (Contributing Editor), Honolulu, Hawaii, USA in the Nassau grouper. J Fish Biol 46:961-976

Sadovy Y, Domeier M (2005) Are aggregation-fisheries sustainable? Reef fish fisheries as a case study. Coral Reefs 24:254-262

Sadovy Y, Eklund AM (1999) Synopsis of the biological data on the Nassau grouper Epinephelus striatus (Bloch, 1792) and the Jewfish, E. itajara (Lichtenstein, 1822) NOAA Tech Rep NMFS 146

Sala E, Ballesteros E, Starr RM (2001) Rapid decline of Nassau grouper spawning aggregations in Belize: fishery management and conservation needs. Fisheries 26:23-30

Smith CL (1972) A spawning aggregation of the Nassau grouper Epinephelus striatus (Bloch). Trans Am Fish Soc 101:257-261

Sokal RR, Rohlf FJ (1995) Biometry, the principles and practice of statistics in biological research, 3rd edn. WH Freeman \& Co, New York

Sosa-Cordero E, Cárdenas-Vidal J (1996) Estudio preliminar de la pesquería de mero Epinephelus striatus del sur de Quintana Roo. Proc Gulf Carib Fish Inst 44:56-72

Sosa-Cordero E, Medina-Quej A, Herrera R, Aguilar-Dávila W (2002) Agregaciones reproductivas de peces en el Sistema Arrecifal Mesoamericano: Consultoría Nacional, Mexico. Sistema Arrecifal Mesoamericano

Whaylen L, Pattengill-Semmens CV, Semmens BX, Bush PG, Boardman MR (2004) Observations of a Nassau grouper, Epinephelus striatus, spawning aggregation site in Little Cayman, Cayman Islands, including multi-species spawning information. Environ Biol Fish 70:305-313

Submitted: June 20, 2005; Accepted: May 10, 2006

Proofs received from author(s): November 13, 2006 